\title{
Sporomusa malonica sp. nov., a homoacetogenic bacterium growing by decarboxylation of malonate or succinate
}

\author{
Irmtraut Dehning ${ }^{1}$, Marion Stieb ${ }^{2}$, and Bernhard Schink ${ }^{1}$ \\ ${ }^{1}$ Lehrstuh1 Mikrobiologie I, Eberhard-Karls-Universität, Morgenstelle 28, D-7400 Tübingen, Federal Republic of Germany \\ ${ }^{2}$ Dornier System GmbH, Space Development Division, D-7900 Friedrichshafen 1, Federal Republic of Germany
}

\begin{abstract}
A new strictly anaerobic bacterium was isolated from an enrichment culture with glutarate as sole substrate and freshwater sediment as inoculum, however, glutarate was not metabolized by the pure culture. The isolate was a mesophilic, spore-forming, Gram-negative, motile curved rod. It fermented various organic acids, alcohols, fructose, acetoin, and $\mathrm{H}_{2} / \mathrm{CO}_{2}$ to acetate, usually as the only product. Other acids were fermented to acetate and propionate or acetate and butyrate. Succinate and malonate were decarboxylated to propionate or acetate, respectively, and served as sole sources of carbon and energy for growth. No inorganic electron acceptors except $\mathrm{CO}_{2}$ were reduced. Yeast extract $(0.05 \% \mathrm{w} / \mathrm{v})$ was required for growth. Small amounts of cytochrome $b$ were detected in membrane fractions. The guanine-plus-cytosine content of the DNA was $44.1 \pm 2 \mathrm{~mol} \%$. The isolate is described as a new species of the genus Sporomusa, S. malonica.
\end{abstract}

Key words: Sporomusa malonica sp. nov. - Gram-negative sporeformer - Homoacetogenesis - Malonic acid decarboxylation - Bioenergetics

Several species of acetogenic bacteria have been described which gain their growth energy by the reduction of carbon dioxide to acetic acid. Clostridium aceticum was the first homoacetogenic bacterium isolated from mud by Wieringa (1940). Other spore-forming Gram-positive acetogens were discovered: C. thermoaceticum (Fontaine et al. 1942), C. formicoaceticum (Andreesen et al. 1970), C. thermoautotrophicum (Wiegel et al. 1981), and C. magnum (Schink 1984).

Also non spore-forming Gram-positive acetogenic bacteria were isolated: Acetobacterium woodii (Balch et al. 1977), A. wieringae (Braun and Gottschalk 1982), $A$. carbinolicum (Eichler and Schink 1984), and the thermophilic Acetogenium kivui (Leigh et al. 1981). Other strains such as Eubacterium limosum (Sharak Genthner et al. 1981) or Butyribacterium methylotrophicum (Zeikus et al. 1980) produce acetate and butyrate during growth with $\mathrm{H}_{2} / \mathrm{CO}_{2}$ or methanol. Recently, Gram-negative spore-forming

Offprint requests to: I. Dehning acetogens were described which were assigned to the new genus Sporomusa (Möller et al. 1984).

We report here on the isolation and characterization of a new Gram-negative spore-forming homoacetogen which oxidizes a broad variety of organic substrates and can also grow by decarboxylation of malonate or succinate as sole energy and carbon sources.

\section{Materials and methods}

Sources of microorganisms

Strain WoGl2 was isolated from enrichment cultures inoculated with anoxic mud of a polluted freshwater creek near Konstanz, FRG. Sporomusa acidovorans DSM 3132 was obtained from the German collection of Microorganisms (DSM), Braunschweig, FRG.

\section{Media and growth conditions}

All procedures for isolation and cultivation were the same as described in earlier papers (Pfennig and Trüper 1981; Widdel and Pfennig 1981). The freshwater mineral medium (Schink and Pfennig 1982) which was carbonate-buffered $(30 \mathrm{mM})$ and sulfide-reduced $(1 \mathrm{mM})$ contained 7 -vitamin solution (Widdel and Pfennig 1981), selenite-tungstate solution, and the trace element solution SL10 (Widdel et al. 1983). The $\mathrm{pH}$ was $7.2-7.4$ and the growth temperature $28-30^{\circ} \mathrm{C}$. Growth was determined by measuring turbidity in a Spectronic 70 spectrophotometer (Bausch and Lomb, Rochester, NY, USA) in $20 \mathrm{ml}$ screw-cap tubes. Substrates were added from sterile, neutralized stock solutions.

For further characterization, also a commercial media system (API 20A, BioMérieux, Nürtingen, FRG) was applied.

\section{Cytological characterization}

Gram-staining was carried out according to Magee et al. (1975) with Acetobacterium woodii and Klebsiella sp. as reference organisms.

Cytochromes were assayed in French press cell extracts as well as in membrane preparations $(150000 \times g, 1 \mathrm{~h})$ by 
redox difference spectroscopy (dithionite-reduced minus airoxidized) in an Uvikon 860 photometer (Kontron, Zürich, Switzerland).

The DNA base composition was determined by thermal denaturation according to De Ley (1970) after extraction as described by Marmur (1961). Escherichia coli strain K12, DSM 498, was used as reference strain.

\section{Chemical analyses}

Sulfide formation from sulfate or sulfur was analyzed by the methylene blue method (Cline 1969), nitrite formation from nitrate with sulfanilic acid and $\alpha$-naphthylamine (Procházková 1959).

Fatty acids were assayed with a Carlo Erba Vega 6000 gas chromatograph (Milano, Italy) with flame ionization detector and a glass column $(2 \mathrm{~m} \times 2 \mathrm{~mm})$ packed with $60 / 80$ Carbopak C/0.3\% Carbowax $20 \mathrm{M} / 0.1 \% \mathrm{H}_{3} \mathrm{PO}_{4}$ (Supelco, Inc., USA). Injector and detector temperatures were $180^{\circ} \mathrm{C}$, column temperature $120^{\circ} \mathrm{C}$, carrier gas nitrogen, $45 \mathrm{ml} / \mathrm{min}$, injection volume $2 \mu \mathrm{l}$. Samples and standards were acidified prior to injection with formic acid to $0.5 \mathrm{M}$ final concentration. Chromatograms were recorded with a MerckHitachi D-2000 integrator (Tokyo, Japan).

Malonate was quantified as dimethyl ester by capillary gas chromatography as described earlier (Dehning and Schink 1989).

All chemicals (analytical grade) were obtained from Fluka, Neu-Ulm, or Merck, Darmstadt, FRG.

\section{Results}

\section{Isolation}

Enrichment cultures in freshwater medium with $10 \mathrm{mM}$ glutarate as sole energy and carbon source were inoculated with freshwater sediment samples. Gas production started after 3-4 weeks, and the glutarate-degrading bacterial community could be transferred at $1: 10$ ratio into subcultures which grew up again within $1-2$ weeks. After the fifth transfer, the culture was diluted in agar shake series with various substrates.

In the dilution series with glutarate as sole substrate, growing colonies were observed only in the first two tubes indicating that the glutarate-degrading bacteria depended on a cooperation with other bacteria. The glutaratefermenting bacteria could not be isolated, no matter whether yeast extract or hydrogen-scavenging methanogens or sulfate reducers were added to the medium.

In agar medium with $10 \mathrm{mM}$ crotonate, brown, lensshaped colonies developed within 2 weeks up to the sixth dilution tube. Colonies were picked with sterile Pasteur pipettes, resuspended in small amounts of anoxic medium, and again diluted in shake series with the same substrate. The resulting isolates were checked for purity by microscopic control and by inoculation into complex AC-medium (Difco, Detroit, MI, USA) with and without added crotonate. The isolated strain WoG12 required yeast extract (at least $0.01 \%$ ) for growth with crotonate in pure culture, and did not utilize glutarate.

\section{Morphology and cytological characterization}

Cells of strain WoGl2 were slightly curved, spore-forming rods with rounded ends, $0.7 \times 2.6-4.8 \mu \mathrm{m}$ in size, occurring

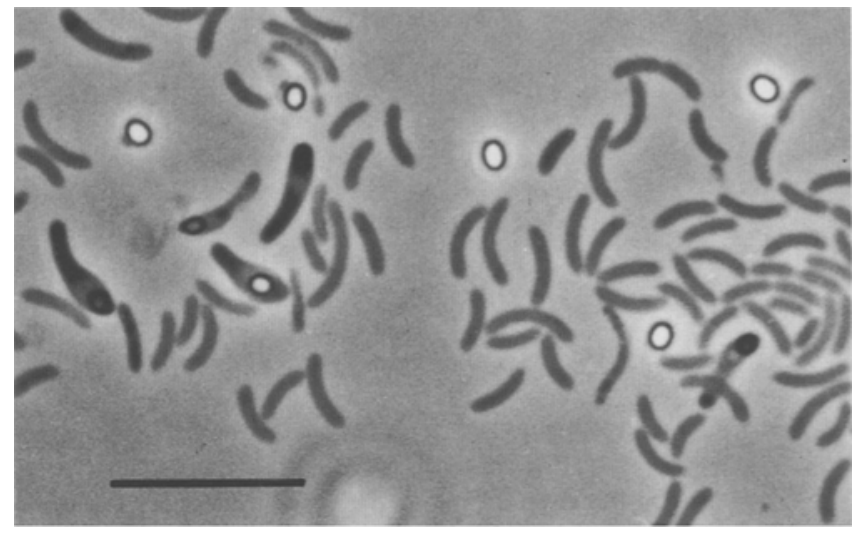

Fig. 1. Phase contrast photomicrograph of the isolate WoGl2 showing vegetative cells, free spores and subterminal spore-formation. Bar equals $10 \mu \mathrm{m}$

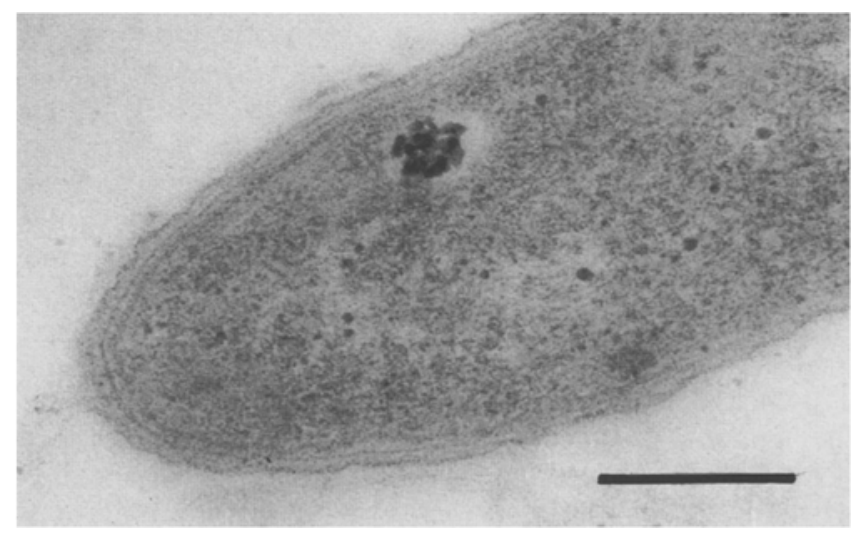

Fig. 2. Electron micrograph of an ultrathin section of strain WoGl2 showing a multilayered cell wall. Bar $=0.2 \mu \mathrm{m}$

mostly single and sometimes in pairs (Fig. 1). Growing cells exhibited tumbling movement. Flagella staining revealed $2-5$ flagella per cell which were inserted on the concave cell side. Oval spores $(1.2 \times 1.5 \mu \mathrm{m})$ were sporadically formed subterminally and were released into the medium (Fig. 1). Spores survived pasteurization at $80^{\circ} \mathrm{C}$ for $15 \mathrm{~min}$.

The Gram staining reaction was negative. Electron micrographs of ultrathin sections showed a typical Gramnegative, multilayered cell wall, consisting of a convoluted outer membrane, a thin peptidoglycan layer, and an inner cytoplasmic membrane (Fig. 2).

Redox difference spectra of cell-free extracts and membrane preparations showed weak absorption bands at about 559,529 , and $428 \mathrm{~nm}$ indicating the presence of a cytochrome $b$ at very low concentration $(1-2 \mathrm{mg} / \mathrm{g}$ protein in the cell-free extract). The spectra did not vary qualitatively or quantitatively, no matter whether malonate or fumarate was used as substrate. No cytochrome was detected in the cytoplasmic fraction.

The guanine-plus-cytosine content of the DNA was determined to be $44.1 \pm 2 \mathrm{~mol} \%$.

Analysis by high-performance liquid chromatography of the corrinoid preparation extracted from this acetogenic bacterium revealed with a high probability a $p$-cresolylcobamide. 


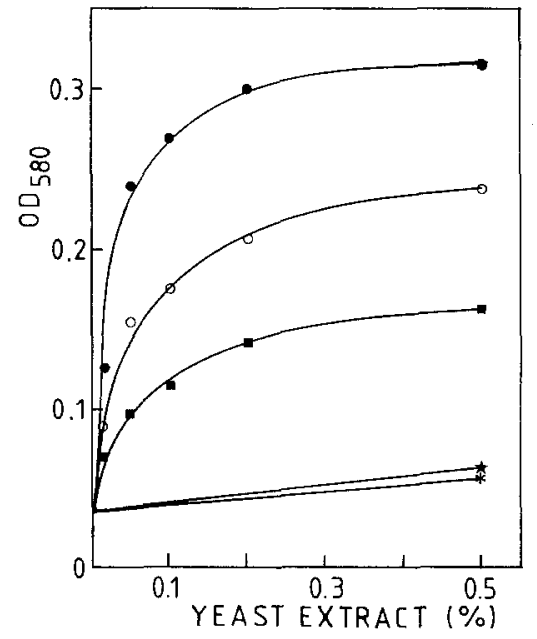

Fig. 3. Dependence of growth of strain WoGl2 on the amount of yeast extract $(\mathrm{w} / \mathrm{v})$ added to mineral medium containing malonate at various concentrations. Symbols: * no malonate, $\star$ no malonate, $10 \mathrm{mM}$ acetate, $10 \mathrm{mM}$ malonate, $020 \mathrm{mM}$ malonate, $30 \mathrm{mM}$ malonate. $\mathrm{OD}_{580}$ : optical density at $580 \mathrm{~nm}$

\section{Physiology and fermentation stoichiometry}

Growth of strain WoGl2 was possible only under strictly anaerobic conditions. The isolate grew in freshwater as well as in brackish water medium containing $10 \mathrm{~g} \mathrm{NaCl}$ and $1.5 \mathrm{~g} \mathrm{MgCl}_{2} \times 6 \mathrm{H}_{2} \mathrm{O}$ per liter, but not in saltwater medium. Phosphate up to $50 \mathrm{mM}$ concentration did not inhibit growth.

Growth occurred only in the presence of at least $0.01 \%$ $(\mathrm{w} / \mathrm{v})$ yeast extract. Higher concentrations stimulated growth (Fig. 3); a concentration of $0.2 \%$ was optimal. However, yeast extract did not serve as energy source. The growth rate with $20 \mathrm{mM}$ malonate and $0.05 \%$ yeast extract was $0.124 \mathrm{~h}^{-1}\left(t_{\mathrm{d}}=5.6 \mathrm{~h}\right)$. With $0.2 \%$ yeast extract, the growth rate was enhanced to $0.182 \mathrm{~h}^{-1}\left(t_{\mathrm{d}}=3.8 \mathrm{~h}\right)$ and the cell yield increased considerably (Fig. 3).

The growth curve (Fig. 4) illustrates the correlation of growth, malonate decomposition, and acetate formation by strain WoG12 in the presence of $0.05 \%$ yeast extract. Growth was possible at temperatures between 15 and $38^{\circ} \mathrm{C}$; the optimum was at $28-32^{\circ} \mathrm{C}$. The optimal $\mathrm{pH}$ was around 7.3, the limits were $\mathrm{pH} 6.0$ and 8.5. No inorganic electron acceptors such as nitrate, sulfate, thiosulfate, sulfite, or sulfur were reduced.

Besides crotonate, strain WoGl2 was able to utilize a variety of substrates listed in Table 1 , including $\mathrm{H}_{2} / \mathrm{CO}_{2}$. Slow growth was also observed with methylmalonate + acetate, betaine, choline, and 2,3-butanediol. Oxalate, glutarate, adipate, pimelate, methylsuccinate, 2- or 3methylglutarate, L-alanine, L-serine, benzoate, indolylacetate, ethylene glycol, glycerol, diacetyl, glucose, xylose, arabinose, lactose, and casamino acids were not metabolized. Growth with the dicarboxylic acids was tested in the presence of $2 \mathrm{mM}$ acetate.

The only fermentation products were acetate, propionate, and butyrate. The stoichiometries of substrate utilization, product formation, and growth yields are presented in Table 1. Crotonate, 3-hydroxybutyrate, and butanol were fermented to acetate and butyrate. Succinate and malonate were decarboxylated to the respective fatty acids. Fumarate, malate, propanol, and 1,2-propanediol were degraded to

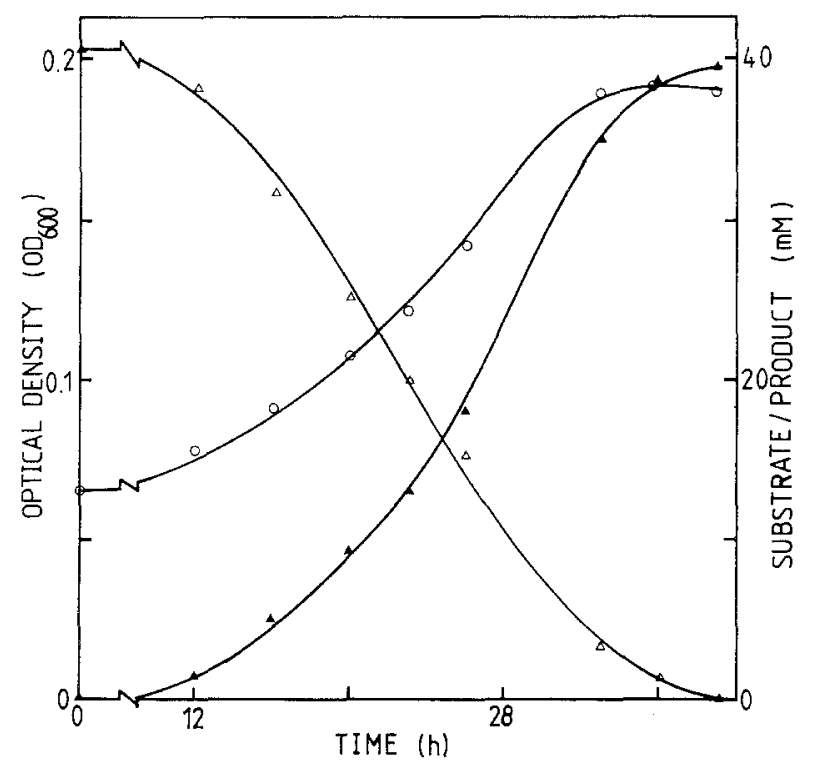

Fig. 4. Fermentation time course of strain WoGl2 in mineral medium containing $40 \mathrm{mM}$ malonate and $0.05 \%(\mathrm{w} / \mathrm{v})$ yeast extract. Experiments were performed at $30^{\circ} \mathrm{C}$ in $130 \mathrm{ml}$ serum bottles. Samples were removed with a syringe and the headspace was flushed with $\mathrm{N}_{2} / \mathrm{CO}_{2}$. Symbols: $O$ cell density, $\Delta$ malonate, $\Delta$ acetate formed

acetate and propionate. The fermentation of citrate, pyruvate, lactate, acetoin, formate, fructose, glutamate, methanol, ethanol, $\mathrm{H}_{2} / \mathrm{CO}_{2}$, and the methoxyl groups of trimethoxycinnamic acid led to acetate as sole fermentation product.

\section{Studies with Sporomusa acidovorans}

Growth experiments with $S$. acidovorans revealed that also this strain produced propionate during growth with succinate. Malate, fumarate, and 1,2-propanediol were fermented to acetate and propionate (Table 2). Malonate, crotonate, and propanol were not metabolized.

\section{Discussion}

\section{Physiology}

The new anaerobic bacterium described in this paper was obtained from freshwater enrichment cultures with glutarate and was isolated with crotonate as sole substrate. Strain WoGI2 exhibited a versatile metabolism fermenting a variety of organic compounds as well as $\mathrm{H}_{2} / \mathrm{CO}_{2}$. Acetate was the main end product; no ethanol or hydrogen were formed. Thus, strain WoGl2 belongs to the physiological group of homoacetogenic bacteria.

Fructose, pyruvate, lactate, citrate, methanol, formate, acetoin, glutamate, the methoxyl groups of trimethoxycinnamic acid, and $\mathrm{H}_{2} / \mathrm{CO}_{2}$ were fermented to only acetate as this is usual for homoacetogens (e.g. Acetobacterium woodii, Clostridium aceticum, C. magnum). Oxidation of ethanol to acetate was already described for Clostridium aceticum (Adamse 1980) and C. formicoaceticum (Andreesen et al. 1970), however, these clostridia could not degrade higher alcohols. The fermentation of propanol, butanol, and 
Table 1. Growth yields and stoichiometry of fermentation of various substrates by strain WoGl2

\begin{tabular}{|c|c|c|c|c|c|c|c|c|c|}
\hline \multirow[t]{2}{*}{ Substrate } & \multirow{2}{*}{$\begin{array}{l}\text { Amount of } \\
\text { substrate } \\
\text { added } \\
(\mu \mathrm{mol})\end{array}$} & \multirow[t]{2}{*}{$\mathrm{OD}_{600}$} & \multirow{2}{*}{$\begin{array}{l}\text { Cell dry } \\
\text { matter } \\
\text { formed } \\
(\mathrm{mg})^{\mathrm{a}}\end{array}$} & \multirow{2}{*}{$\begin{array}{l}\text { Acetate } \\
\text { assimi- } \\
\text { lated } \\
(\mu \mathrm{mol})^{\mathbf{b}}\end{array}$} & \multicolumn{3}{|c|}{ Products formed $(\mu \mathrm{mol})$} & \multirow{2}{*}{$\begin{array}{l}\text { Electron } \\
\text { recovery } \\
(\%)\end{array}$} & \multirow{2}{*}{$\begin{array}{l}\text { Growth } \\
\text { yield } \\
(\mathrm{g} / \mathrm{mol})\end{array}$} \\
\hline & & & & & Acetate & $\begin{array}{l}\text { Propio- } \\
\text { nate }\end{array}$ & Butyrate & & \\
\hline Crotonate & 200 & 0.28 & 1.4 & 29 & 228 & & 81 & 113 & 7.0 \\
\hline 3-OH-Butyrate & 200 & 0.26 & 1.3 & 27 & 196 & & 64 & 96 & 6.5 \\
\hline Succinate & 200 & 0.09 & 0.45 & $10^{\mathrm{c}}$ & & 184 & & 97 & 2.25 \\
\hline Malonate & 200 & 0.08 & 0.4 & 8 & 183 & & & 96 & 2.0 \\
\hline Malate & 200 & 0.36 & 1.8 & 37 & 144 & 81 & & 112 & 9.0 \\
\hline Fumarate & 200 & 0.35 & 1.75 & 36 & 121 & 90 & & 110 & 8.75 \\
\hline Citrate & 100 & 0.26 & 1.3 & 27 & 212 & & & 106 & 13.0 \\
\hline Pyruvate & 100 & 0.14 & 0.7 & 14.5 & 110 & & & 100 & 7.0 \\
\hline Lactate & 200 & 0.25 & 1.25 & 26 & 271 & & & 99 & 6.25 \\
\hline Acetoin & 200 & 0.38 & 1.9 & 39 & 477 & & & 103 & 9.5 \\
\hline Formate & 100 & 0.04 & 0.2 & 4 & 26 & & & 117 & 2.0 \\
\hline Fructose & 40 & 0.35 & 1.75 & 36 & 89 & & & 104 & 43.75 \\
\hline Trimethoxycinnamic acid & 50 & 0.21 & 1.05 & 22 & 83 & & & 93 & 21.0 \\
\hline Methanol & 100 & 0.16 & 0.8 & 17 & 62 & & & 105 & 8.0 \\
\hline Ethanol & 200 & 0.11 & 0.55 & 11 & 290 & & & 100 & 2.75 \\
\hline Propanol & 200 & 0.09 & 0.45 & 10 & 113 & 175 & & 99 & 2.25 \\
\hline Butanol & 200 & 0.08 & 0.4 & 8 & 114 & & 186 & 103 & 2.0 \\
\hline 1,2-Propanediol & 200 & 0.24 & 1.2 & 24 & 72 & 167 & & 105 & 6.0 \\
\hline Glutamate & 200 & 0.19 & 0.9 & 19 & 202 & & & 97 & 9.4 \\
\hline
\end{tabular}

All growth tests were carried out in $20 \mathrm{ml}$ tubes completely filled with mineral medium in the presence of $0.05 \%$ (w/v) yeast extract. The background production with yeast extract alone was $\mathrm{OD}_{60.0}=0.01$ and was subtracted from the values measured with the above substrates. All figures are means of two independent assays

${ }^{a}$ Cell dry matter was calculated from turbidity at $600 \mathrm{~nm}$ using the conversion factor $0.1 \mathrm{OD}_{600}=25.0 \mathrm{mg} / \mathrm{l}$, which was obtained by direct determinations with $500 \mathrm{ml}$ cultures grown with crotonate

${ }^{b}$ Assimilation of acetate into cell material was calculated by the equation: $17 \mathrm{C}_{2} \mathrm{H}_{3} \mathrm{O}_{2}^{-}+11 \mathrm{H}_{2} \mathrm{O} \rightarrow 8\left\langle\mathrm{C}_{4} \mathrm{H}_{7} \mathrm{O}_{3}\right\rangle+2 \mathrm{HCO}_{3}^{-}+15 \mathrm{OH}^{-}$; thus, $20.6 \mu \mathrm{mol}$ acetate was required for $1.0 \mathrm{mg}$ of cell dry matter

${ }^{c}$ Assimilation of succinate: $17 \mathrm{C}_{4} \mathrm{H}_{4} \mathrm{O}_{4}^{2-}+32 \mathrm{H}_{2} \mathrm{O} \rightarrow 14\left\langle\mathrm{C}_{4} \mathrm{H}_{7} \mathrm{O}_{3}\right\rangle+12 \mathrm{HCO}_{3}^{-}+22 \mathrm{OH}^{-}$

Table 2. Stoichiometry of fermentation of succinate, malate, and 1,2-propanediol by Sporomusa acidovorans

\begin{tabular}{lllc}
\hline Substrate & $\begin{array}{l}\text { Amount of } \\
\text { substrate } \\
\text { added }(\mu \mathrm{mol})\end{array}$ & Acetate & Propionate \\
\cline { 4 - 4 } & 200 & & 187 \\
Succinate & 200 & 245 & 11 \\
Malate & 200 & 23 & 189 \\
1,2-Propanediol & & &
\end{tabular}

Experiments were carried out in mineral medium in the presence of $0.05 \%$ yeast extract

1,2-propanediol to acetate and the respective fatty acids was demonstrated with Acetobacterium carbinolicum (Eichler and Schink 1984).

Crotonate and 3-hydroxybutyrate were degraded to acetate and butyrate according to the following equation (for crotonate):

$2 \mathrm{C}_{4} \mathrm{H}_{5} \mathrm{O}_{2}^{-}+2 \mathrm{H}_{2} \mathrm{O} \rightarrow 2 \mathrm{C}_{2} \mathrm{H}_{3} \mathrm{O}_{2}^{-}+\mathrm{C}_{4} \mathrm{H}_{7} \mathrm{O}_{2}^{-}+\mathrm{H}^{+}$.

Strain WoGl2 formed more acetate than expected from this equation (Table 1). Obviously, the bacteria carried out two different fermentation patterns simultaneously, crotonate dismutation and homoacetogenic fermentation. A similar fermentation was reported for Clostridium kluyveri (Thauer et al. 1968) and Ilyobacter polytropus (Stieb and Schink 1984). It was shown recently that also obligately syntrophic fatty acid-oxidizing bacteria can grow in pure culture by the same dismutation of crotonate (Beaty and McInerney 1987).

Malate and fumarate were fermented to acetate and propionate. In this case as well (Table 1), more acetate was formed than expected from the classical fermentation equation for propionibacteria, e.g., Veillonella sp. (for malate):

$3 \mathrm{C}_{4} \mathrm{H}_{4} \mathrm{O}_{5}^{2-}+3 \mathrm{H}^{+} \rightarrow$

$2 \mathrm{C}_{3} \mathrm{H}_{5} \mathrm{O}_{2}^{-}+\mathrm{C}_{2} \mathrm{H}_{3} \mathrm{O}_{2}^{-}+4 \mathrm{CO}_{2}+\mathrm{H}_{2} \mathrm{O}$.

Apparently, propionic acid fermentation and homoacetogenic fermentation were performed simultaneously. The presence of small amounts of cytochrome $b$ indicates that energy could perhaps be conserved by electron transport phosphorylation coupled to fumarate reduction. However, the cell yields obtained do not provide conclusive evidence for this hypothesis. The bacteria are obviously not able to carboxylate pyruvate to oxaloacetate as do the classical propionibacteria. This is probably the reason why lactate is not fermented to propionate.

Of special interest is the ability of strain WoGl2 to grow by decarboxylation of malonate and succinate to acetate or propionate, respectively (for malonate):

$\mathrm{C}_{3} \mathrm{H}_{2} \mathrm{O}_{4}^{2-}+\mathrm{H}^{+} \rightarrow \mathrm{C}_{2} \mathrm{H}_{3} \mathrm{O}_{2}^{-}+\mathrm{CO}_{2}$.

Growth by decarboxylation of a dicarboxylic acid was so far studied with only one bacterium, Propionigenium modestum, growing on succinate (Schink and Pfennig 1982). This bacterium forms ATP from the small free energy change of the decarboxylation reaction (around $-20 \mathrm{~kJ} / \mathrm{mol}$ ) (Thauer et al. 1977) by coupling the decarboxylation of 
methylmalonyl-CoA by a membrane-bound decarboxylase to sodium ion extrusion and sodium ion-dependent ATP synthesis (Hilpert et al. 1984).

The low growth yields of $2.4 \mathrm{~g}$ per mol succinate with $P$. modestum, $2.0 \mathrm{~g}$ per mol malonate with the newly isolated bacterium Malonomonas rubra (Dehning and Schink 1989), and $2.25 \mathrm{~g}$ per mol succinate ( 2.0 with malonate) with strain WoGl2 (Table 1) correlate with this small change in free energy. It will be a subject of further research to examine whether succinate and malonate fermentation by strain WoGl2 use a similar energy coupling system as does succinate fermentation by $P$. modestum.

The cell yields of strain WoGl2 obtained after growth with various substrates were in the same range as those of A. carbinolicum (Eichler and Schink 1984) growing with the same substrates. However, all growth yields with the exception of pyruvate were higher than those of I.polytropus (Stieb and Schink 1984), probably because strain WoGl2 can gain additional ATP by acetogenic $\mathrm{CO}_{2}$ reduction. The reduction of bicarbonate as an external electron acceptor allows the concomitant oxidation of the respective organic substrate to acetate, and enhances the yield of conserved metabolic energy.

\section{Taxonomy}

The new acetogenic spore-forming bacterium showed a typical Gram-negative cell wall. This feature excludes it from the Gram-positive clostridia. Other autotrophically growing acetogens like Acetobacterium sp. (e.g. Balch et al. 1977), Acetogenium kivui (Leigh et al. 1981), Eubacterium limosum (Sharak Genthner et al. 1981), or Butyribacterium methylotrophicum (Zeikus et al. 1980) have similar physiological properties, however, they do not form spores and are Gram-positive.

The fermentation of various organic compounds as well as $\mathrm{H}_{2} / \mathrm{CO}_{2}$ to mainly acetate, the banana-shaped cell form, the Gram-negative cell wall architecture, spore-formation, unilaterally inserted flagella, the $\mathrm{G}+\mathrm{C}$ content of the DNA of $44 \mathrm{~mol} \%$, and the likely presence of $p$-cresolylcobamide (Stupperich et al. 1988) indicate that strain WoGl2 is closely related to the genus Sporomusa. Within this genus, five species have been described. Our isolate differs from $S$. ovata, S. sphaeroides (Möller et al. 1984), and S. paucivorans (Hermann et al. 1987) by using fumarate, malate, citrate, succinate, and malonate as substrates. S. acidovorans (Ollivier et al. 1985) is able to grow with various organic acids, but does not utilize crotonate, citrate, lactate, malonate, ethanol, and propanol. Unlike the new isolate, $S$. acidovorans could grow with glycerol and serine, and the $\mathrm{pH}$ optimum for growth was around 6.5. The recently described species $S$. termitida (Breznak et al. 1988) isolated from gut contents of termites, can also decarboxylate succinate and malonate. However, this bacterium did not use fructose, propanol, fumarate, or malate, and fermentation of lactate or mannitol led to acetate and ethanol as end products. Thus, we propose to assign the described strain WoG12 to the genus Sporomusa as a new species, S. malonica.

\section{Species description}

Sporomusa malonica sp. nov., ma.lo'ni.ca, M.L.n. acidum malonicum malonic acid, malonica M.L.fem.adj., referring to metabolization of malonic acid.
Sporulating, curved rods, $0.7 \times 2.6-4.8 \mu \mathrm{m}$ in size, Gram-negative. Motile by laterally inserted flagella, occurring singly or in pairs. Spores oval, $1.2 \times 1.5 \mu \mathrm{m}$, subterminal, heat-resistant.

Strictly anaerobic chemoorganotroph or autotroph. Crotonate and 3-hydroxybutyrate, as well as butanol fermented to acetate and butyrate. Succinate and malonate degraded to propionate or acetate, respectively. Malate and fumarate, as well as propanol and 1,2-propanediol fermented to acetate and propionate. Citrate, pyruvate, lactate, fructose, methanol, ethanol, glutamate, acetoin, formate, $\mathrm{H}_{2} / \mathrm{CO}_{2}$, and methoxyl groups of trimethoxycinnamic acid metabolized to acetate. No other organic acids, sugars, or alcohols metabolized.

Growth in freshwater and brackish water mineral salts medium with small amounts of yeast extract $(0.05 \% \mathrm{w} / \mathrm{v})$. Sulfate, thiosulfate, sulfite, sulfur, or nitrate not reduced. Indole not formed, gelatin or urea not hydrolyzed; no catalase activity. Mesophilic; temperature range: $15-38^{\circ} \mathrm{C}$, optimum around $30^{\circ} \mathrm{C}$. $\mathrm{pH}$ range: $6.0-8.5$, optimum at 7.3. Membrane-bound cytochrome $b$. DNA base composition: $44.1 \pm 2 \mathrm{~mol} \% \mathrm{G}+\mathrm{C}$ (thermal denaturation). Habitat: anaerobic sediment of freshwater origin. Type strain: WoGl2, DSM 5090, deposited with the Deutsche Sammlung von Mikroorganismen (DSM), Braunschweig.

Acknowledgement. The authors thank Prof.Dr. Frank Mayer, Göttingen, and his coworkers for electron microscopic characterization of the new isolate. The preliminary characterization of the corrinoid by Hans Jürgen Eisinger, Ulm, is gratefully acknowledged. This work was supported by a grant of the Deutsche Forschungsgemeinschaft.

\section{References}

Adamse AD (1980) New isolation of Clostridium aceticum (Wieringa). Antonie van Leeuwenhoek $\mathrm{J}$ Microbiol Serol $46: 523-531$

Andreesen JR, Gottschalk G, Schlegel HG (1970) Clostridium formicoaceticum nov. spec. Isolation, description and distinction from $C$. aceticum and $C$. thermoaceticum. Arch Mikrobiol $72: 154-174$

Balch WE, Schoberth S, Tanner RS, Wolfe RS (1977) Acetobacterium, a new genus of hydrogen-oxidizing, carbon dioxidereducing, anaerobic bacteria. Int J Syst Bacteriol 27:355-361

Beaty PS, McInerney MJ (1987) Growth of Syntrophomonas wolfei in pure culture on crotonate. Arch Microbiol 147:389-393

Braun M, Gottschalk G (1982) Acetobacterium wieringae sp. nov., a new species producing acetic acid from molecular hydrogen and carbon dioxide. Zbl Bakt Hyg, I Abt Orig C3:368-376

Breznak JA, Switzer JM, Seitz H-J (1988) Sporomusa termitida sp. nov., an $\mathrm{H}_{2} / \mathrm{CO}_{2}$-utilizing acetogen isolated from termites. Arch Microbiol 150:282-288

Cline JD (1969) Spectrophotometric determination of hydrogen sulfide in natural waters. Limnol Oceanogr 14:454-458

Dehning I, Schink B (1989) Malonomonas rubra gen. nov. sp. nov., a microaerotolerant anacrobic bacterium growing by decarboxylation of malonate. Arch Microbiol 151:427-433

De Ley J (1970) Reexamination of the association between melting point, buoyant density and the chemical base composition of deoxyribonucleic acid. J Bacteriol 101:738 - 754

Eichler B, Schink B (1984) Oxidation of primary aliphatic alcohols by Acetobacterium carbinolicum sp. nov., a homoacetogenic anaerobe. Arch Microbiol 140:147-152

Fontaine FE, Peterson WH, McCoy E, Johnson MJ, Riter GJ (1942) A new type of glucose fermentation by Clostridium thermoaceticum nov. sp. J Bacteriol 43:701-715 
Hermann M, Popoff M-R, Sebald M (1987) Sporomusa paucivorans sp. nov, a methylotrophic bacterium that forms acetic acid from hydrogen and carbon dioxide. Int J Syst Bacteriol 37:93 101

Hilpert W, Schink B, Dimroth P (1984) Life by a new decarboxylation-dependent energy conservation mechanism with $\mathrm{Na}^{+}$ as coupling ion. EMBO J 3:1665-1670

Leigh JA, Mayer F, Wolfe RS (1981) Acetogenium kivui, a new thermophilic hydrogen-oxidizing acetogenic bacterium. Arch Microbiol 129:275-280

Magee CM, Rodeheaver G, Edgerton MT, Edlich RF (1975) A more reliable Gram staining technic for diagnosis of surgical infections. Am J Surg 130:341 - 346

Marmur J (1961) A procedure for the isolation of deoxyribonucleic acid from microorganisms. J Mol Biol 3:208-218

Möller B, Oßmer R, Howard BH, Gottschalk G, Hippe H (1984) Sporomusa, a new genus of Gram-negative anaerobic bacteria including Sporomusa sphaeroides spec. nov. and Sporomusa ovata spec. nov. Arch Microbiol 139:388-396

Ollivier B, Cordruwisch R, Lombardo A, Garcia JL (1985) Isolation and characterization of Sporomusa acidovorans sp. nov., a methylotrophic homoacetogenic bacterium. Arch Microbiol 142:307-310

Pfennig N, Trüper HG (1981) Isolation of members of the families Chromatiaceae and Chlorobiaceae. In: Starr MP, Stolp H, Trüper HG, Balows A, Schlegel HG (eds) The prokaryotes, vol I. Springer, Berlin, pp 279-289

Procházková L (1959) Bestimmung der Nitrate im Wasser. Z Anal Chem 167:254-260

Schink B (1984) Clostridium magnum sp. nov., a non-autotrophic homoacetogenic bacterium. Arch Microbiol 137:250-255

Schink B, Pfennig N (1982) Propionigenium modestum gen. nov. sp. nov., a new strictly anaerobic, nonsporing bacterium growing on succinate. Arch Microbiol 133:209-216

Sharak Genthner BR, Davie CL, Bryant MP (1981) Features of rumen and sewage sludge strains of Eubacterium limosum, a methanol- and $\mathrm{H}_{2}$ - $\mathrm{CO}_{2}$-utilizing species. Appl Environ Microbiol 42:12-19

Stieb M, Schink B (1984) A new 3-hydroxybutyrate fermenting anaerobe, Ilyobacter polytropus gen. nov. sp. nov., possessing various fermentation pathways. Arch Microbiol 140:139-146

Stupperich E, Eisinger HJ, Kräutler B (1988) Diversity of corrinoids in acetogenic bacteria. Eur J Biochem 172:459-464

Thauer RT, Jungermann K, Henninger $\mathrm{H}$, Wenning $\mathrm{H}$, Decker $\mathrm{K}$ (1968) The energy metabolism of Clostridium kluyveri. Eur J Biochem 4:173-180

Thauer RK, Jungermann K, Decker K (1977) Energy conservation of chemotrophic anaerobic bacteria. Bacteriol Rev 41:100180 .

Widdel F, Pfennig N (1981) Studies on dissimilatory sulfate-reducing bacteria that decompose fatty acids. I. Isolation of a new sulfate-reducer enriched with acetate from saline environments. Description of Desulfobacter postgatei gen. nov. sp. nov. Arch Microbiol 129:395-400

Widdel F, Kohring GW, Mayer F (1983) Studies on dissimilatory sulfate-reducing bacteria that decompose fatty acids. III. Characterization of the filamentous gliding Desulfonema limicola gen., nov. sp. nov., and Desulfonema magnum sp. nov. Arch Microbiol 134:286-294

Wiegel J, Braun M, Gottschalk G (1981) Clostridium thermoautotrophicum species novum, a thermophile producing acetate from molecular hydrogen and carbon dioxide. Curr Microbiol $5: 255-260$

Wieringa KT (1940) The formation of acetic acid from carbon dioxide and hydrogen by anaerobic spore-forming bacteria. Antonie van Leeuwenhoek J Microbiol Serol 6:251-262

Zeikus JG, Lynd LH, Thompson TE, Krzycki JA, Weimer PJ, Hegge PW (1980) Isolation and characterization of a new, methylotrophic, acidogenic anaerobe, the Marburg strain. Curr Microbiol 3:381 - 386

Received October 17, 1988/Accepted January 15, 1989 